\title{
Antiheparin activity of some human blood protein fractions and their possible relationship to thrombosis
}

\author{
F. DEWHURST AND L. POLLER
}

From Withington Hospital, Manchester

SYNOPSIS In view of the possible relationship to thrombosis the 'anti-heparin' activity of blood protein fractions was studied. Serum and plasma were separated by continuous paper curtain electrophoresis and two different groups of fractions with anti-heparin activity found. One group was associated with the fast $\gamma$ globulins and the other with the $\alpha$ globulins. The fast $\gamma$ activity appeared to be identical with the contact activation product (activated factors XI and XII). The $\alpha$ globulin activity is different from any of the known serum clotting factors. This activity may be due to a previously unrecognized clotting factor or may be a coagulant property of certain blood proteins which act by binding heparin.

The clinical implications of these findings are discussed. It is suggested that the fast $\gamma$ globulin anti-heparin fraction may be identical with Wessler's serum thrombotic accelerator and the $\alpha$ globulin activity is a separate entity.

The blood of patients who have recently experienced thrombotic episodes clots more rapidly in the presence of heparin than the blood of normal adults. This has been found in tests both in vivo and in vitro (Crafoord, 1937; Waugh and Ruddick, 1944; Soulier and Le Bolloch, 1951; Poller, 1954). Serum and serum extracts prepared by adsorption have been shown to contain considerable anti-heparin activity (Poller, 1960). A powerful thrombogenic agent has been demonstrated in serum by infusion experiments (Wessler, 1952; Wessler and Reimer, 1960), and this thrombogenic activity appears to be similar in some physical properties to the 'anti-heparin' activity of serum (Poller, 1961).

In view of the possible clinical linkage between the anti-heparin activity of blood and thrombosis a study has been made of anti-heparin activity in normal human serum and plasma. Blood protein fractions obtained by continuous paper curtain electrophoresis were examined for clotting activity. The findings shed new light upon the anti-heparin activity of normal blood and suggest the presence of a previously unrecognized coagulant activity of normal blood.

\section{METHOD OF STUDY}

Paper curtain continuous electrophoresis was used to Received for publication 1 December 1964. fractionate blood proteins because this method gives a good separation of plasma and serum clotting activities (Lewis, Walters, Didisheim, and Merchant, 1958). The electrophoretic fractions were desalted, concentrated, and investigated for anti-heparin activity. The effect of the fractions upon the intrinsic (blood) thromboplastin generation system was studied by their effect upon the recalcification time of normal plasma. To investigate the relationship between anti-heparin activity and 'contact' activity (activated factors XI and XII) the effect of the fractions upon the silicone clotting time and the stearateactivated clotting time of normal plasma was studied. The fractions were examined for factor VII, factor IX, and factor $\mathrm{X}$ activity to investigate the possible relationship between these factors and anti-heparin activity. The serum fractions were examined for thrombin activity as this is present in serum. In the studies on plasma fractions the presence of prothrombin and fibrinogen was determined for the sake of completeness. Factor $\mathrm{V}$ is unstable and would be unlikely to withstand the fractionation procedures described in this paper. Preliminary experiments suggested that little or no factor VIII activity survived. In view of this instability and the fact that factors V and VIII are found only in plasma, whilst anti-heparin activity is found in serum, they were ignored in the present study.

The separated fractions were analysed for protein content and further characterized by paper strip electrophoresis.

In the light of the findings in the present study the effect of stearate activation of the substrate plasma upon the anti-heparin activity of serum and plasma was examined. 


\section{MATERIAL AND METHODS}

SERUM Blood was taken from normal healthy adults and allowed to clot in glass containers. After storage at $4^{\circ} \mathrm{C}$. for 24 hours, the serum was removed and centrifuged for five minutes at $1,750 \times g$. When not used immediately the serum was stored at $-20^{\circ} \mathrm{C}$.

NORMAL PLASMA Blood was collected, using plastic syringes, from normal healthy adult donors, citrated, spun down in plastic tubes at $1,750 \times g$ for five minutes and the plasma separated. The normal plasma was either stored in plastic containers and used within a few hours or quickly freeze-dried in glass ampoules and stored at $-20^{\circ} \mathrm{C}$. until required.

FACTOR-VII-DEFICIENT PLASMA The plasma was obtained as described above from patients commencing nicoumalone (Sinthrome) treatment and the fresh plasma stored at $-20^{\circ} \mathrm{C}$. until required. The factor-VII-deficient plasma used gave a very prolonged Quick prothrombin time on collection, a normal result in the thromboplastin generation test, and the deficiency was corrected by normal serum.

IMIDAZOLE BUFFER Imidazole (glyoxaline) saline buffer was made up as described by Biggs and Macfarlane (1962). This buffer was used in all the coagulation tests.

HEPARIN-RETARDED CLOTTING TIME (POLLER, 1954, MODIFIED) Substrate plasma $(0.2 \mathrm{ml}$.) was added to $0.2 \mathrm{ml}$. of $\frac{M}{40}$ calcium chloride in buffer, $0.1 \mathrm{ml}$. of heparin (1 unit per $\mathrm{ml}$.) in buffer, and $0.2 \mathrm{ml}$. of saline and/or serum fraction, and the tube was gently tilted every 15 seconds until a fibrin web began to form. The tests and all other clotting tests described in this paper were carried out at $37^{\circ} \mathrm{C}$.

PLASMA RECALCIFICATION TIME Normal substrate plasma $\left(0.2 \mathrm{ml}\right.$.) was added to $0.2 \mathrm{ml}$. of $\frac{\mathrm{M}}{40}$ calcium chloride, in buffer, and $\mathbf{0 . 2} \mathrm{ml}$. of saline and/or protein fraction. The tube was gently tilted until a clot formed.

ONE-STAGE PROTHROMBIN TIME Substrate plasma (0.1 ml.) was added to $0.1 \mathrm{ml}$. of thromboplastin, $0.1 \mathrm{ml}$. of $\frac{M}{40}$ calcium chloride, in buffer, and $0.1 \mathrm{ml}$. of saline or serum fraction and the tube gently tilted until a clot formed. Factor-VII-deficient plasma was used as substrate plasma so that the clotting time observed was shortened by the presence of factor VII activity in the serum fractions. The thromboplastin was a phenolized saline extract of human brain. (Poller, 1964.)

THROMBIN TIME The presence of thrombin was tested for by adding $0.2 \mathrm{ml}$. of serum fraction to $0.2 \mathrm{ml}$. of a $1 \%$ solution of fibrinogen in buffer and periodically examining the solution for evidence of clotting. The fibrinogen used was bovine Cohn fraction I.
FACTOR X ACTIVITY The presence of factor X (Stuar Prower factor) in the electrophoretic fractions was de? tected by the method of Denson (1961). Diagen factor substrate plasma $(0.1 \mathrm{ml}$.) was added to $0.1 \mathrm{ml}$. of saline or electrophoretic extract and $0 \cdot 1 \mathrm{ml}$. of $1 / 150,00 \mathrm{~g}$ Stypven, Russell viper venom, in diluted human brai cephalin (Hjort, Rapaport, and Owren, 1955). Thirt产 seconds later $\frac{M}{40}$ buffered calcium chloride $(0 \cdot 1 \mathrm{ml}$.) wa added and the clotting time recorded.

FACTOR IX ACTIVITY The thromboplastin generation test (Biggs and Douglas, 1953) was used to demonstrate the presence of factor IX (Christmas factor) activity in thes electrophoretic fractions. The generation mixture consisted of $0.1 \mathrm{ml}$. of adsorbed diluted normal plasmạs $0.1 \mathrm{ml}$. of platelet substitute (Bell and Alton, 1954), $0.1 \mathrm{ml}$. of diluted serum from a patient suffering frorf severe congenital factor IX deficiency, $0.1 \mathrm{ml}$. of saline of electrophoretic fraction, and $0.1 \mathrm{ml}$. of $\frac{\mathrm{M}}{40}$ buffered calcium chloride solution. After generation for six minute at $37^{\circ} \mathrm{C} \cdot 0 \cdot 1 \mathrm{ml}$. of the mixture was added simultaneous with $0.1 \mathrm{ml}$. of citrated normal plasma to $0.1 \mathrm{ml}$. of buto fered $\frac{M}{40}$ calcium chloride and the clotting time recorded.

PROTHROMBIN The presence of prothrombin in the electrophoretic fractions was demonstrated using the one stage prothrombin time of adsorbed sheep plasma to which fibrinogen and serum had been added. The tese system consisted of $0.2 \mathrm{ml}$. of Seitz-filtered sheep plasm疓 $0.1 \mathrm{ml}$. of a $1 \%$ solution of fibrinogen in buffer, $0.1 \mathrm{ml}$. normal human serum, $0.2 \mathrm{ml}$. of $\frac{\mathrm{M}}{40}$ buffered calciu码 chloride, $0.2 \mathrm{ml}$. of thromboplastin, and $0.2 \mathrm{ml}$. of salin or electrophoretic fraction.

DETECTION OF FIBRINOGEN The presence of fibrinogen the electrophoretic fractions was demonstrated by the addition of $0.2 \mathrm{ml}$. of buffered thrombin $(200 \mu / \mathrm{ml}$.) to $0.2 \mathrm{ml}$. of each fraction.

SILICONE CLOTTING TIMES Buffered $\frac{M}{40}$ calcium chlorid底 $(0.1 \mathrm{ml}$.) was added to platelet substitute $(0.1 \mathrm{ml}$. saline or electrophoretic fraction $(0 \cdot 1 \mathrm{ml}$.), and substrate plasma $(0 \cdot 1 \mathrm{ml}$.) in a siliconed tube. The tube was gentl tilted and the clotting time recorded. The tubes and pipettes were coated with I.C.I. silicone M.441 and the substrate plasma stored in plastic tubes.

STEARATE SOLUTIONS Buffered $3 \mathrm{mEq}$./1. suspensions of sodium stearate were prepared (Nossel, 1964).

STEARATE-ACTIVATED CLOTTING TIMES This method based on Nossel's observations on the stearate activation of the contact system (Nossel, 1964). Stearate suspension (0 $\mathrm{ml}$.) and normal citrated plasma $(0 \cdot 1 \mathrm{ml}$.) were incubateg 


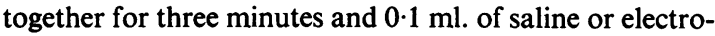
phoretic fraction and $0 \cdot 1 \mathrm{ml}$. of buffered $\frac{\mathrm{M}}{40}$ calcium chloride added. The tube was gently tilted and the clotting

PAPER CURTAIN ELECTROPHORESIS This was carried out in pH $8.6 \mu=0.05$ borate buffer on $3 \mathrm{MM}$ paper at $18 \mathrm{ma}$. and 400-450 volts. The $\alpha_{1}$ globulin component cannot be separated from albumin in borate buffers but this buffer gives an excellent separation of the other globulins (Consden and Powell, 1955).

Serum was fed on to the curtain at a rate of $1.1 \mathrm{ml}$. per day using a motor-driven syringe. Sodium azide $(1 \%)$ was added to the serum before electrophoresis to minimize bacterial growth. After electrophoresis the fractions were desalted and concentrated by dialysing to dryness against Carbowax $20 \mathrm{M}$ in Visking tubing. The fractions were then redissolved by dialysis against normal saline for several hours, made up to the desired volume by adding normal saline and stored at $-20^{\circ} \mathrm{C}$.

PAPER STRIP ELECTROPHORESIS The dialysed fractions were characterized by electrophoresis in $p \mathrm{H} 8.6 \mu=0.1$ veronal acetate buffer. The strips were stained with Lissamine green.

PROTEIN ESTIMATION The protein content of the serum fractions was estimated by a modification of Lowry's method (Leggett Bailey, 1962).

\section{RESULTS}

Anti-heparin activity was found to be present in two separate groups of serum protein fractions, from the effect of the fractions upon the heparin-retarded clotting time of normal plasma. One group of these fractions was associated with the $\alpha$ globulins and one with the fast $\gamma$ globulins. The fast $\gamma$ globulin fractions time recorded.

also produced a considerable shortening of the plasma clotting (recalcification) time of normal plasma without added heparin. The $\alpha$ globulin fractions also showed feeble thrombin activity.

The results of a typical experiment are shown in Tables I and II. In this particular experiment $6.6 \mathrm{ml}$. of pooled serum (from three donors) was electrophoresed and each fraction made up to a volume of $3 \mathrm{ml}$. after dialysis. Thrombin activity was observed in fractions 10 and 11 which produced a definite clot with fibrinogen in about 24 hours. The residual serum in the syringe when electrophoresis was complete clotted fibrinogen in about one and a half

\section{TABLE II}

EFFECT OF SERUM PROTEIN FRACTIONS UPON THE RECALCIFICATION TIME OF NORMAL PLASMA AND THE 'ONE-STAGE' PROTHROMBIN TIME OF FACTOR-VII-DEFICIENT PLASMA

\begin{tabular}{|c|c|c|c|c|}
\hline \multirow[t]{3}{*}{$\begin{array}{l}\text { Fraction } \\
\text { No. }\end{array}$} & \multicolumn{2}{|c|}{ Recalcification Time (sec.) } & \multirow{2}{*}{\multicolumn{2}{|c|}{$\begin{array}{l}\text { One-stage Prothrombin Time } \\
\text {-(sec.) (duplicate } \\
\text { determinations) }\end{array}$}} \\
\hline & \multicolumn{2}{|c|}{ Protein Fraction (ml.) } & & \\
\hline & $0 \cdot 2$ & $0 \cdot 1$ & & \\
\hline 1 & 163 & 165 & 73 & 74 \\
\hline 2 & 163 & 160 & 76 & 70 \\
\hline 3 & 124 & 132 & 75 & 76 \\
\hline 4 & 91 & 107 & 72 & 74 \\
\hline 5 & 104 & 122 & 72 & 72 \\
\hline 6 & 111 & 134 & 73 & 78 \\
\hline 7 & 141 & 135 & 57 & 58 \\
\hline 8 & 172 & 168 & 29 & 30 \\
\hline 9 & 166 & 164 & 23 & 25 \\
\hline 10 & 173 & 170 & 23 & 24 \\
\hline 11 & 174 & 175 & 26 & 29 \\
\hline 12 & 182 & 168 & 47 & 44 \\
\hline 13 & 168 & 170 & 61 & 65 \\
\hline 14 & 148 & 148 & 67 & 68 \\
\hline 15 & 175 & 170 & 75 & 78 \\
\hline 16 & 175 & 166 & 75 & 72 \\
\hline $\begin{array}{l}\text { Original } \\
\text { serum }\end{array}$ & & & & \\
\hline Saline & 165 & 170 & 79 & 81 \\
\hline
\end{tabular}

TABLE I

EFFECT OF SERUM PROTEIN FRACTIONS UPON THE HEPARIN-RETARDED CLOTTING TIME OF PLASMA

\begin{tabular}{|c|c|c|c|c|}
\hline \multirow[t]{3}{*}{ Fraction No. } & \multirow{3}{*}{$\begin{array}{l}\text { Protein }(\mu g .) \text { per } \\
\text { Millilitre }\end{array}$} & \multicolumn{3}{|c|}{ Heparin-retarded Clotting Time $(G)$} \\
\hline & & \multicolumn{3}{|c|}{ Protein Fraction ( $\mathrm{ml})}$. \\
\hline & & 0.2 & $0 \cdot 1$ & 0.05 \\
\hline $\begin{array}{l}1 \\
2 \\
3 \\
4 \\
5 \\
6 \\
7 \\
8 \\
9 \\
10 \\
11 \\
12 \\
13 \\
14 \\
15 \\
16 \\
\text { Original serum } \\
\text { Saline }(0 \cdot 2 \mathrm{ml} .)\end{array}$ & $\begin{array}{r}4,920 \\
7,240 \\
7,000 \\
4,400 \\
3,240 \\
4,640 \\
4,480 \\
5,560 \\
4,320 \\
6,640 \\
12,100 \\
39,600 \\
13,700 \\
1,120 \\
560 \\
200 \\
65,500\end{array}$ & $\begin{array}{l}5 \text { min. } 30 \mathrm{sec} . \\
5 \mathrm{~min} .15 \mathrm{sec} . \\
5 \mathrm{~min} .15 \mathrm{sec} . \\
3 \mathrm{~min} .30 \mathrm{sec} . \\
4 \mathrm{~min} .15 \mathrm{sec} . \\
5 \mathrm{~min} .00 \mathrm{sec} . \\
5 \mathrm{~min} .30 \mathrm{sec} \text {. } \\
5 \mathrm{~min} .30 \mathrm{sec} . \\
5 \mathrm{~min} .45 \mathrm{sec} . \\
4 \mathrm{~min} .00 \mathrm{sec} . \\
4 \mathrm{~min} .15 \mathrm{sec} . \\
5 \mathrm{~min} .30 \mathrm{sec} . \\
5 \mathrm{~min} .45 \mathrm{sec} . \\
5 \mathrm{~min} .45 \mathrm{sec} . \\
5 \mathrm{~min} .30 \mathrm{sec} . \\
5 \mathrm{~min} .45 \mathrm{sec} . \\
3 \mathrm{~min} .00 \mathrm{sec} . \\
5 \mathrm{~min} .30 \mathrm{sec} .\end{array}$ & 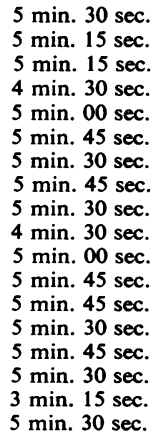 & $\begin{array}{l}5 \mathrm{~min} .30 \mathrm{sec} . \\
5 \mathrm{~min} .30 \mathrm{sec} . \\
5 \mathrm{~min} .15 \mathrm{sec} \text {. } \\
4 \mathrm{~min} .45 \mathrm{sec} . \\
5 \mathrm{~min} .30 \mathrm{sec} \text {. } \\
5 \mathrm{~min} .30 \mathrm{sec} . \\
5 \mathrm{~min} .15 \mathrm{sec} \text {. } \\
5 \mathrm{~min} .45 \mathrm{sec} . \\
5 \mathrm{~min} .45 \mathrm{sec} . \\
5 \mathrm{~min} .00 \mathrm{sec} \text {. } \\
5 \mathrm{~min} .15 \mathrm{sec} \text {. } \\
5 \mathrm{~min} .45 \mathrm{sec} . \\
5 \mathrm{~min} .30 \mathrm{sec} . \\
5 \mathrm{~min} .45 \mathrm{sec} \text {. } \\
5 \mathrm{~min} .30 \mathrm{sec} . \\
5 \mathrm{~min} .30 \mathrm{sec} . \\
3 \mathrm{~min} .30 \mathrm{sec} \text {. } \\
5 \mathrm{~min} .30 \mathrm{sec} .\end{array}$ \\
\hline
\end{tabular}


hours. In Tables I and II 'original serum' refers to the residual serum from the syringe.

Neither of the anti-heparin activities coincided with factor VII, IX, and X activities in the fractions. In fact, fractions containing high levels of factors VII, IX, and X showed no 'anti-heparin' activity, although some overlap occurred between the activities. The results obtained in typical experiments are shown in Tables II and IV.

The fast $\gamma$ globulin anti-heparin activity was found in the fractions most active in shortening the silicone clotting time of normal plasma. No shortening of the clotting time of stearate (contact) activated plasma by the fractions was observed. The results of a typical set of experiments are shown in Table III.

The separation obtained by electrophoresis is illustrated in Figure I. The fractions are those described in Tables I and II.

The plasma fractions studied appeared to contain the same two anti-heparin activities as serum. The fast $\gamma$ globulin fractions also produced a marked shortening of the recalcification time of normal substrate plasma. The anti-heparin activities of plasma appeared to be of the same order as the activities in serum. The plasma fractions appeared to contain very little fibrinogen which suggests that the fibrinogen became denatured in the course of the fractionation. The 'contact' factor activity of the
TABLE III

RELATIONSHIP BETWEEN 'CONTACT FACTOR' AND ANTIHEPARIN ACTIVITIES IN SERUM PROTEIN FRACTIONS

\begin{tabular}{|c|c|c|c|c|c|c|c|c|c|}
\hline $\begin{array}{l}\text { Fraction } \\
\text { No. }\end{array}$ & $\begin{array}{l}\text { Protein } \\
(\mu g .) \text { per } \\
\text { Millilitre }\end{array}$ & $\begin{array}{l}\text { Hepa } \\
\text { retar } \\
\text { Clot } \\
\text { Time }\end{array}$ & $\begin{array}{l}\text { in- } \\
\text { led } \\
\text { (min.) }\end{array}$ & $\begin{array}{l}\text { Plasma } \\
\text { Clotting } \\
\text { Time (sec.) }\end{array}$ & $\begin{array}{l}\text { Silic } \\
\text { Tim } \\
\text { (sec }\end{array}$ & & & & $\frac{2}{5}$ \\
\hline 1 & 350 & $7 \cdot 45$ & 8.00 & 190 & 185 & 189 & 82 & 85 & \\
\hline 2 & 500 & $8 \cdot 15$ & $8 \cdot 15$ & 192 & 185 & 172 & 87 & 83 & \\
\hline 3 & 400 & $8 \cdot 15$ & 8.00 & 203 & 150 & 152 & 83 & 85 & \\
\hline 4 & 2,400 & $8 \cdot 15$ & 9.00 & 205 & 206 & 208 & 88 & 84 & \\
\hline 5 & 5,550 & $8 \cdot 15$ & $8 \cdot 15$ & 200 & 201 & 219 & 84 & 80 & \\
\hline 6 & 7,900 & $8 \cdot 15$ & $8 \cdot 30$ & 190 & 120 & 125 & 84 & 85 & \\
\hline 7 & 6,100 & $6 \cdot 15$ & $6 \cdot 15$ & 150 & 79 & 73 & 81 & 78 & \\
\hline 8 & 4,900 & $7 \cdot 45$ & $7 \cdot 45$ & 168 & 91 & 92 & 78 & 84 & \\
\hline 9 & 6,450 & $9 \cdot 30$ & $9 \cdot 30$ & 180 & 126 & 120 & 78 & 85 & \\
\hline 10 & 5,000 & 8.45 & 9.00 & 210 & 213 & 223 & 87 & 82 & \\
\hline 11 & $4 \cdot 150$ & $7 \cdot 45$ & $7 \cdot 45$ & 203 & 202 & 215 & 87 & 86 & \\
\hline 12 & 7,750 & $5 \cdot 15$ & $5 \cdot 30$ & 215 & 225 & 216 & 83 & 79 & \\
\hline 13 & 16,750 & 6.00 & 5.45 & 216 & 188 & 195 & 84 & 81 & \\
\hline 14 & 31,000 & 8.00 & $7 \cdot 30$ & 214 & 187 & 194 & 86 & 79 & \\
\hline 15 & 11,850 & $8 \cdot 15$ & 8.00 & 200 & 195 & 196 & 78 & 83 & \\
\hline 16 & 1,650 & 8.00 & $8 \cdot 15$ & 202 & 187 & 193 & 82 & 84 & \\
\hline 17 & 600 & 8.00 & $8 \cdot 15$ & 197 & 193 & 200 & 86 & 81 & \\
\hline 18 & 450 & $7 \cdot 30$ & 8.00 & 202 & 186 & 186 & 79 & 86 & \\
\hline Saline & & 8.00 & $8 \cdot 15$ & 208 & 215 & 226 & 85 & 88 & \\
\hline
\end{tabular}

plasma fractions, as measured by the silicone clotting times, was of the same order as that found in the serum fractions.

The results of the coagulation tests applied to the plasma fractions are summarized in Figure 2.

In seven separations of pooled normal serum anकै

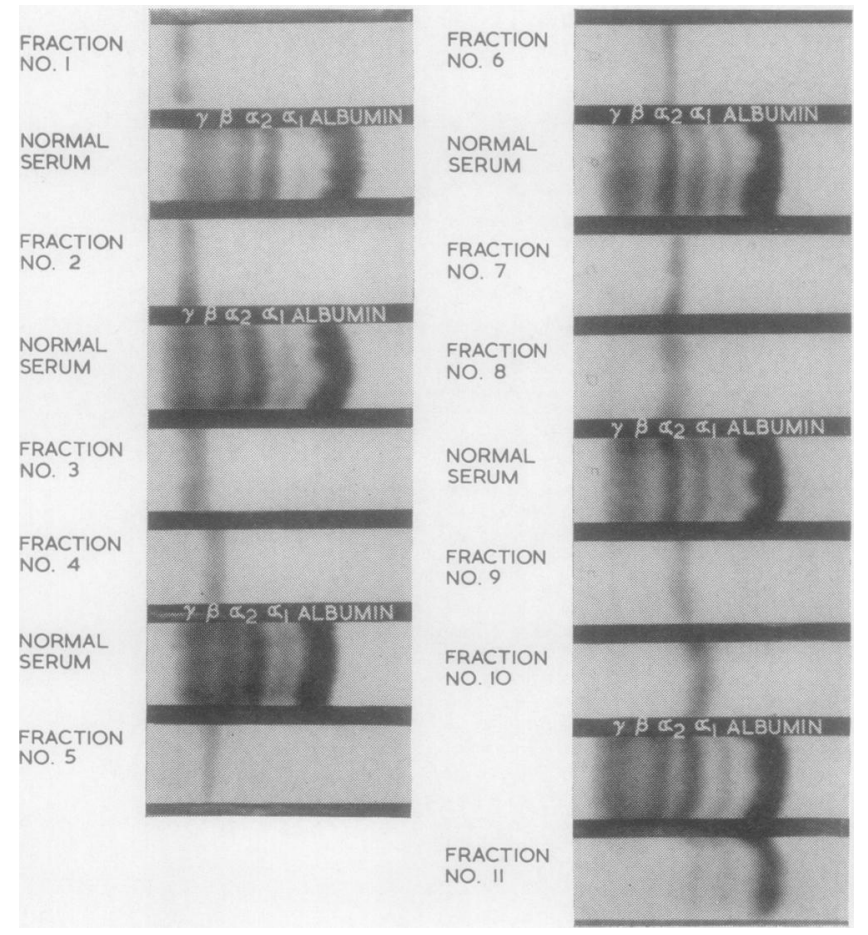

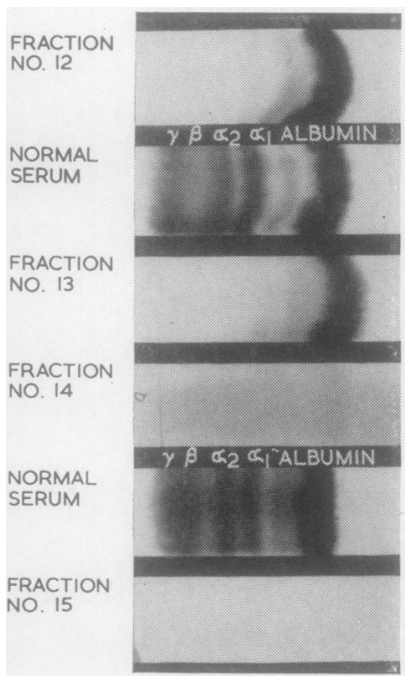

FIG. 1. Separation of fractions by electrophoresis described in Tables I and II. 


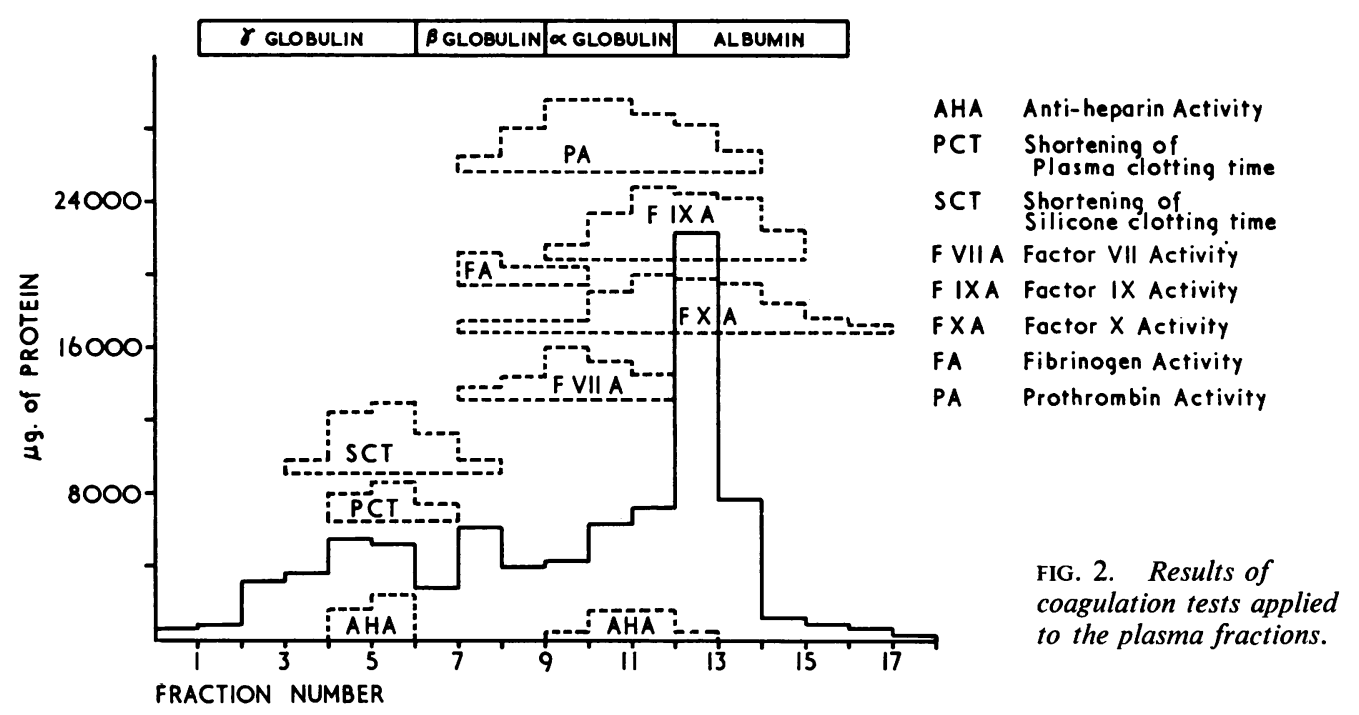

TABLE IV

RELATIONSHIP BETWEEN FACTOR IX AND FACTOR $X$ AND ANTIHEPARIN ACTIVITIES IN SERUM PROTEIN FRACTIONS

\begin{tabular}{|c|c|c|c|c|}
\hline $\begin{array}{l}\text { Fraction } \\
\text { No. }\end{array}$ & $\begin{array}{l}\text { Protein } \\
\text { ( } \mu \text { g.) per } \\
\text { Millilitre }\end{array}$ & $\begin{array}{l}\text { Heparin- } \\
\text { retarded } \\
\text { Clotting } \\
\text { Time } \\
\text { (min.) }\end{array}$ & $\begin{array}{l}\text { 'Six-minute' } \\
\text { Thromboplastin } \\
\text { Generation Time } \\
\text { Using Factor- } \\
\text { IX-deficient } \\
\text { Serum (sec.) }\end{array}$ & $\begin{array}{l}\text { Viper Venom } \\
\text { Clotting Time } \\
\text { of Factor-X- } \\
\text { deficient } \\
\text { Plasma (sec.) }\end{array}$ \\
\hline
\end{tabular}

\begin{tabular}{lrrrrr}
\hline 1 & 1,000 & $8 \cdot 00$ & $8 \cdot 15$ & 35 & - \\
2 & 300 & $8 \cdot 45$ & $9 \cdot 00$ & 38 & - \\
3 & 100 & $8 \cdot 00$ & $7 \cdot 45$ & 36 & - \\
4 & 1,950 & $8 \cdot 30$ & $8 \cdot 45$ & 40 & - \\
5 & 8,700 & $8 \cdot 45$ & $8 \cdot 45$ & 37 & - \\
6 & 5,200 & $8 \cdot 30$ & $7 \cdot 45$ & 34 & - \\
7 & 5,900 & $5 \cdot 45$ & $5 \cdot 30$ & 30 & - \\
8 & 3,500 & $6 \cdot 00$ & $6 \cdot 00$ & 31 & - \\
9 & 5,000 & $7 \cdot 15$ & $7 \cdot 15$ & 32 & 78 \\
10 & 3,900 & $9 \cdot 15$ & $9 \cdot 00$ & 33 & 67 \\
11 & 3,500 & $8 \cdot 00$ & $8 \cdot 00$ & 26 & 67 \\
12 & 6,600 & $6 \cdot 00$ & $6 \cdot 30$ & 28 & 28 \\
13 & 13,900 & $5 \cdot 30$ & $5 \cdot 15$ & 21 & 15 \\
14 & $23 \cdot 500$ & $7 \cdot 30$ & $6 \cdot 45$ & 18 & 17 \\
15 & 20,200 & $9 \cdot 15$ & $9 \cdot 00$ & 18 & 17 \\
16 & 7,350 & $9 \cdot 15$ & $9 \cdot 00$ & 24 & 24 \\
17 & 750 & $9 \cdot 15$ & $9 \cdot 00$ & 23 & 82 \\
18 & 250 & $9 \cdot 15$ & $8 \cdot 30$ & 20 & \\
Saline & - & $8 \cdot 45$ & $8 \cdot 15$ & 36 & \\
& & $9 \cdot 00$ & $9 \cdot 00$ & &
\end{tabular}

\section{TABLE V}

EFFECT OF STEARATE ACTIVATION OF SUBSTRATE PLASMA UPON ANTIHEPARIN ACTIVITY OF SERUM AND PLASMA ${ }^{1}$

No stearate added

Stearate added

Stearate and serum added

Stearate and plasma added

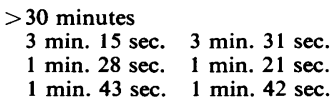

${ }^{1}$ The test system consisted of $0.1 \mathrm{ml}$. of heparin ( $\left.1 \mathrm{unit} / \mathrm{ml}.\right), 0.25 \mathrm{ml}$. of stearate solution or imidazole buffer, $0.25 \mathrm{ml}$. of test plasma or citrate/saline, and $0.25 \mathrm{ml}$. of normal substrate plasma which had been stored in plastic and handled with silicone-coated pipettes.

After three minutes' incubation, at $37^{\circ} \mathrm{C}$. in plastic tubes, $0.25 \mathrm{ml}$. of test serum or saline was added followed by $0.25 \mathrm{ml}$. of calcium chloride. The clotting time was then recorded. The test plasma and serum both came from the same patient. three of plasma similar results were obtained. The distribution of most of the clotting activities was determined each time and no activity was determined on less than three sets of fractions.

It was also found (see Table V) that stearate activation of the substrate plasma greatly reduced the anticoagulant activity of heparin. It was also found that the addition of serum or plasma to stearate-activated plasma produced a further shortening of the heparin-retarded clotting time.

\section{DISCUSSION}

The results indicate that the fast $\gamma$ globulin antiheparin activity is due to a 'contact' activation product (activated factors XI and XII). The fact that these fractions did not produce any shortening of the clotting time of stearate-activated plasma but did shorten the silicone clotting time of normal plasma implies that this activity is due solely to a contact activation product. If an accelerator of intrinsic (blood) clotting activity other than 'contact' activation product were responsible it might be expected to produce a shortening of the clotting time of stearate-activated plasma.

The shortening of the plasma recalcification and the heparin-retarded clotting times when the tests were performed in glass is explicable in terms of the relatively slow contact activation of plasma by glass.

The $\alpha$ globulin anti-heparin activity, which was of the same order as the fast $\gamma$, was not associated with any of the recognized serum clotting factors (factors VII, IX, and X). This is consistent with the observation (Poller, 1960) that the anti-heparin activity of serum from phenindione-treated patients, whose 
thromboplastin generation was less than $1 \%$, was, if anything, greater than normal. These patients were probably deficient in factors VII, IX, and X. This $\gamma$ globulin anti-heparin activity may be due to a previously unrecognized clotting factor activity or may be due to certain proteins present in these fractions which act by binding heparin in a nonspecific manner.

The thrombin activity found in this work confirms the presence of free thrombin activity in stored serum. This activity, which was found in the globulin fractions, was, however, too feeble to account for the anti-heparin activity of these fractions.

It is perhaps surprising that the anti-heparin activities of serum and plasma fractions were of a similar order as more activity is present in serum than plasma. This is explicable in terms of the contact activation of the plasma which must certainly have occurred during electrophoresis. This explanation is perhaps supported by the fact that the contact product activities were of the same order in the serum and plasma fractions, and by the effect of stearate activation of the substrate plasma upon the anti-heparin activity of serum and plasma.

The increased anti-heparin activity found in the blood of patients who have recently experienced a thrombotic episode may be explained in more than one way. It may be the cause of the thrombotic episode or may result from it. In the light of our present findings it could be caused by activation in vivo of the contact system. It has recently been shown (Connor, Hoak, and Warner, 1963) that the injection of sodium stearate produces experimental thrombosis. The increased anti-heparin activity could also arise from contact activation as a direct consequence of established intravascular clotting or the release of serum products from a thrombus into the circulation.

The role of the $\alpha$ globulin anti-heparin activity is not certain. It may possibly be of importance in the development of a thrombotic episode. Further work is in progress to clarify the problem. We have shown that it is not factors VII, IX, or X and it appears too differ from Wessler's 'serum thrombotic accelerator'? which is associated with factors XI and XII. It iss? possible, however, that serum thrombotic ac-o celerator is identical with the fast $\gamma$ globulin activityo found in normal serum and activated plasma.

The distribution of the recognized coagulation factors between the fractions was basically similar tow previous findings (Lewis et al., 1958) although a somewhat different technique was used in the present study. The results also indicate that using $\overrightarrow{\vec{\omega}}$ very simple apparatus a good degree of separation of some blood clotting activities can be obtained by continuous paper curtain electrophoresis.

A grant from the Manchester Regional Hospital Board for thrombosis research is gratefully acknowledged $\mathcal{C}_{\mathcal{O}}$ Additional thanks are due to Dr. P. L. Sequeira for the provision of some facilities for electrophoresis, and to Dr. M. C. G. Israels for the donation of blood from patients with Christmas disease.

\section{REFERENCES}

Bell, W. N., and Alton, H. G. (1954). Nature (Lond.), 174, 880. Biggs, R., and Douglas, A. S. (1953). J. clin. Path., 6, 23. , and Macfarlane, R. G. (1962) Human Blood Coagulation, 3rd ed. p. 79 and p. 369 . Blackwell, Oxford.

Consden, R., and Powell, M. N. (1955). J. clin. Path., 8, 150.

Connor, W. E., Hoak, J. C., and Warner, E. D. (1963). J. clin. Invest $42,860$.

Crafoord, C. (1937). Acta chir. scand., 79, 407.

Denson, K. W. (1961). Acta haemat. (Basel), 25, 105.

Hjort, P., Rapaport, S. I., and Owren, P. A. (1955). J. Lab. clin. Med 46, 89.

Leggett Bailey, J. (1962). Techniques in Protein Chemistry, p. 29 Elsevier, Amsterdam and London.

Lewis, J. H., Walters, D., Didisheim P., and Merchant, W. R. (1958) J. clin. Invest., 37, 1323.

Nossel, H. L. (1964). The Contact Phase of Blood Coagulation, p. 24 and p. 125. Blackwell, Oxford

Poller, L. (1954). Angiology, 5, 21.

(1960). J. clin. Path., 13, 226

(1961), Lancet, 2, 374.

Soulier, J. P., and Le Bolloch, A. G. (1951). Acta med. scand. 140, 13Z

Waugh, T. R., and Ruddick, D. W. (1944). Canad. med. Ass. J., 50, 547

Wessler, S. (1952). J. clin. Invest., 31, 1011.

—, and Reimer, S. M. (1960). Ibid., 39, 262. 